\title{
Recent advances on blinatumomab for acute lymphoblastic leukemia
}

\author{
Juanjuan Zhao ${ }^{1}$, Yongping Song ${ }^{1}$ and Delong Liu ${ }^{1,2^{*}}$
}

\begin{abstract}
Although complete remission rate of B cell acute lymphoblastic leukemia (B-ALL) has improved significantly over the past few decades, patients with relapsed/refractory ALL still have dismal outcome. Tyrosine kinase inhibitors, antibody-drug conjugates and chimeric antigen receptor T cell therapy are changing the therapy landscape for B- ALL. Blinatumomab, a bi-specific T cell engager, has been approved for patients with relapsed/refractory and minimal residual disease positive B-ALL. This review summarized data from recent clinical trials of blinatumomab for B-ALL treatment.
\end{abstract}

Keywords: Acute lymphoblastic leukemia, Blinatumomab, BiTE, Bispecific T cell engager

\section{Background}

Chemotherapy combined with targeted therapies and improved supportive care has enhanced complete remission (CR) rate of newly diagnosed $B$ cell acute lymphoblastic leukemia (B-ALL) to 85-90\%, and long-term survival rate to $40-45 \%$ [1]. However, about a third of standard-risk and two-thirds of high-risk patients experience recurrence [2, 3]. Relapsed and refractory $(\mathrm{r} / \mathrm{r})$ ALL has low rates of $C R$ and poor long-term survival $[2,4,5]$. A retrospective analysis of $1706 \mathrm{r} / \mathrm{r}$ B-ALL patients without Philadelphia chromosome $(\mathrm{Ph})$ and aged younger than 65 years showed that the CR rates were respectively $40 \%, 21 \%, 11 \%$ and 3 -year survival rate were $11 \%$, $5 \%$, $4 \%$ for first, second, and $\geq 3$ rd salvage therapy, indicating progressively worse prognosis with each subsequent relapse [6]. Efforts are being made to improve the outcome of R/R ALL. First of all, to better define the disease status for guiding further therapy for consolidation and maintenance, minimal residual disease (MRD) is characterized more precisely with real-time quantitative PCR and multiparametric flow cytometry. MRD is defined as positive if blast cells are detected at above $0.01 \%$ level [7]. Next-generation sequencing (NGS) is

\footnotetext{
*Correspondence: delong_liu@nymc.edu

${ }^{1}$ Department of Hematology, The Affiliated Cancer Hospital

of Zhengzhou University and Henan Cancer Hospital, Zhengzhou, China

Full list of author information is available at the end of the article
}

increasingly used for monitoring MRD and better predicting early relapse $[8,9]$. About $30-50 \%$ of adults and $10-20 \%$ of children with ALL achieved MRD- negative CR [10-14]. MRD is currently recognized as the most significant indicator for ALL relapse at all ages [15-17]. A meta-analysis of a total of 39 studies including 13,637 ALL individuals showed a significant correlation between negative MRD and 10-year EFS $(\mathrm{HR}=0.23$ for pediatric subjects and $=0.28$ for adult subjects) and $\mathrm{OS}(\mathrm{HR}=0.28$ for pediatric subjects and $=0.28$ for adult subjects) [18]. Secondly, to add targeted agents such as tyrosine kinase inhibitors and CD20 antibodies to chemotherapy regimens when appropriate biomarker targets are present [19-26]. CD19 is expressed in normal and malignant B cells [27-30]. Engineered T cells with CD19- targeted chimeric antigen receptors (CAR $\mathrm{T}$ ) are widely studied for R/R ALL [31-33]. Recently, a CD19 × CD3 bispecific $\mathrm{T}$ cell engager (BiTE), blinatumomab (Blincyto, Amgen), has been developed [34]. Blinatumomab contains CD3 and CD19 single-chain variable regions linked by a glycine-serine linker. It binds selectively to CD3 expressing $\mathrm{T}$ cells and CD19 expressing B cells, leading to the formation of immune synapses between $T$ cells and $B$ cells $[35,36]$. This redirects unstimulated cytotoxic $\mathrm{T}$ cells to specifically target and lyse CD19-positive B cells, both malignant and normal B cells. The blinatumomab BiTE single-chain antibody fragment has a molecular weight of $54 \mathrm{kDa}$. Blinatumomab is administered through 
continuous IV infusion for 4 weeks followed by a 2-week interval [37-39]. Similar to CAR T therapy, cytokine release syndrome (CRS) and neurotoxicity are the two major adverse events associated with blinatumomab therapy [38, 40, 41]. Blinatumomab achieved accelerated US Food and Drug Administration (FDA) approval for R/R ALL (Fig. 1) [42, 43]. Blinatumomab has been approved for treatment of R/R ALL in 53 countries [44]. This review summarized recent updates on clinical trials of blinatumomab for B-ALL.

\section{Blinatumomab clinical trials for ALL Blinatumomab for R/R ALL}

In a phase 2 clinical trial of blinatumomab for $R / R$ B-ALL, a total of 36 patients were enrolled. The CR/CRh rate was $69 \%(25 / 36)$ after the first two cycles. Among the responders, $88 \%(22 / 25)$ achieved a molecular remission. The MRD-negative response rate was $69 \%$. It was noticed that the quality of response was worse in second or greater relapse. With a median follow-up of 9.7 months (m), the median relapse-free survival (RFS) was $7.6 \mathrm{~m}$ [45]. Since CD19+ normal B cells were also affected, lymphopenia was the most frequent severe adverse event (SAE). After cessation of therapy, lymphopenia became reversable. After longer follow-up (median 33 months), $80 \%$ MRD-negative response rate was reported [46]. This study with long-lasting complete remission in R/R B-lineage ALL patients laid foundation for further expanded clinical investigation.

In a separate large, multicenter, phase II trial (MT103211, NCT01466179), 189 adult patients with Ph-negative
$R / R$ B cell ALL were enrolled to further assess the clinical activity of blinatumomab [38]. Patients who relapsed within 12 months after allogeneic hematopoietic stem cell transplantation (allo-HSCT) were included. Stepwise dose ramp-up of blinatumomab was used to minimize initial CRS and neurotoxicities. Blinatumomab was infused at $9 \mu \mathrm{g} /$ day for the first week, followed by $28 \mu \mathrm{g} /$ day for the remaining 3 weeks. Treatment was cycled every 6 weeks. The results showed that CR/CRh was achieved in $43 \%$ of the patients (33\% CR $+10 \%$ $\mathrm{CRh}$ ) after the first two cycles. The median RFS was $5.9 \mathrm{~m}$ (median follow-up of $8.9 \mathrm{~m}$ ), and the median OS was $6.1 \mathrm{~m}$ (median follow-up of $9.8 \mathrm{~m}$ ) [38]. Among the 81 patients who achieved $\mathrm{CR} / \mathrm{CRh}, 40 \%$ proceeded to allo-HSCT. Febrile neutropenia and anemia were common adverse events (AE). Severe CRS events including hypoxia, high fever and hypotension were reported in 3 patients. Tremors, seizure and mental status changes were reported as common neurotoxicity. It was noticed that $20 \%$ of the patients who received blinatumomab in this study were still alive after 2 years. Therefore, the data from this study were compared with historical data with long-term outcome from $1139 \mathrm{Ph}$ negative B-ALL patients [47]. The long-term survival was estimated [47]. The estimated long-term $(60 \mathrm{~m})$ OS rate $(12.4 \%$ vs $5.4 \%$ ) and median OS (76.1 vs $38.6 \mathrm{~m}$ ) of this clinical trial were significantly better than those from historical group before blinatumomab era. Even though these were not the results from a randomized study, these findings implied that blinatumomab has the potential to be better than salvage chemotherapy.

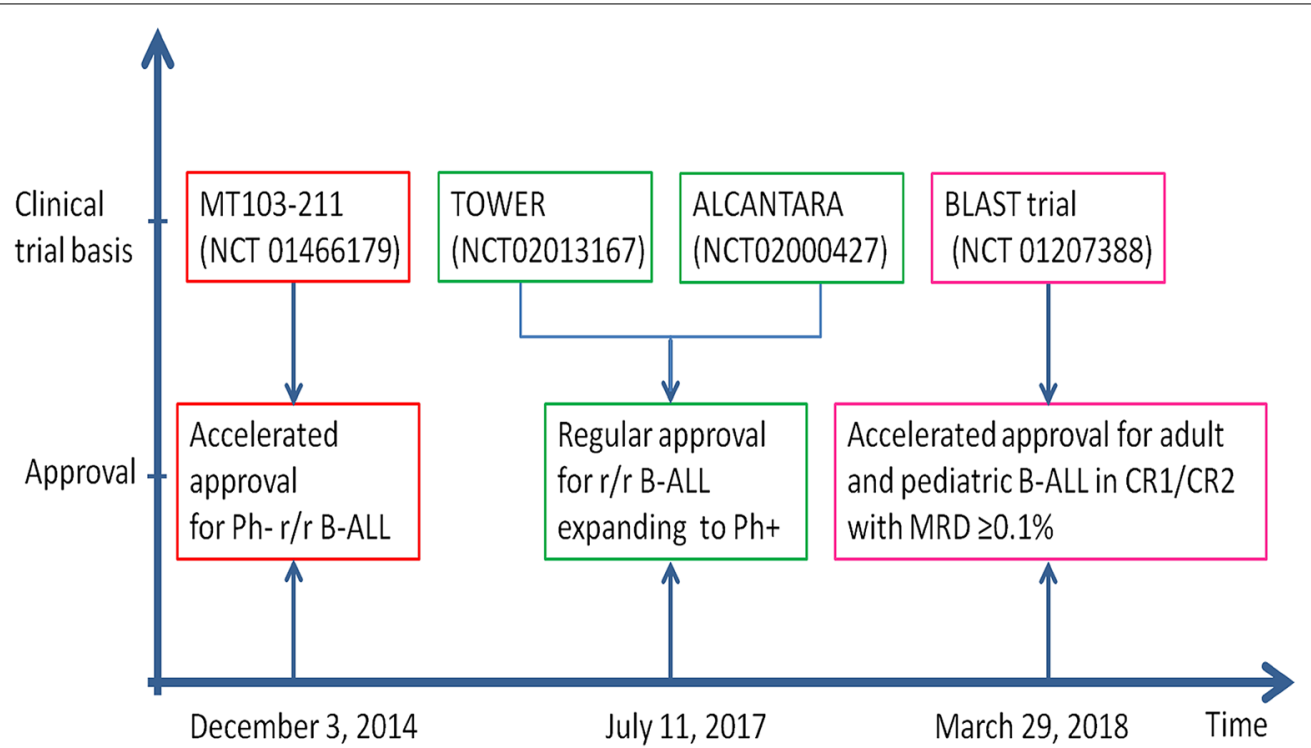

Fig. 1 The approval timeline of blinatumomab by US FDA. $r / r$ refractory/relapsed 
To confirm the efficacy of blinatumomab for R/R ALL, a phase III randomized trial (the TOWER trial, NCT 02013167) was done to compare blinatumomab versus salvage chemotherapy. This study enrolled 405 patients. The patients were randomized in a 2:1 ratio. 271 patients received blinatumomab, 124 patients received salvage chemotherapy. Compared with salvage chemotherapy, blinatumomab monotherapy had better OS $(7.7 \mathrm{~m}$ vs $4.0 \mathrm{~m}, \mathrm{P}=0.01)$, $\mathrm{CR}$ rate $(34 \%$ vs $16 \%$ in 12 weeks, $\mathrm{P}<0.001)$ and $\mathrm{EFS}$ rate $(31 \%$ vs $12 \%$ at $6 \mathrm{~m}, \mathrm{P}<0.001)$ in $\mathrm{r} / \mathrm{r}$ B-ALL patients [48].

\section{Blinatumomab for MRD+ ALL}

MRD remains measurable in 30 to $50 \%$ of adult ALL patients in hematologic $\mathrm{CR}$ after chemotherapy. It has been well established that positive MRD in ALL is associated with higher relapse rate and poor OS [17]. Allo-HSCT was reported to increase the 5-year RFS of MRD+ALL from 11 to 44\% [12].

An analysis of 20 evaluable ALL patients treated with blinatumomab revealed negative MRD in 16 of them, suggesting deep response in $80 \%$ patients [49]. The final analysis of this study reported a median follow-up of 50.8 months. Half of the 20 patients $(50 \%)$ remained in CR 5 years after the initial treatment [50].

Blinatumomab was examined in MRD+B-ALL patients in a multicenter open-label single-arm phase 2 study in patients with MRD $+\left(\geq 10^{-3}\right)$ B-ALL who were in CR1 or CR 2/3. Among the 116 patients enrolled, 113 patients who received blinatumomab were evaluable. Among these, $78 \%$ were found to have negative MRD (MRD responders) after 1 cycle of blinatumomab. Compared with MRD non-responders, MRD responders had longer RFS (23.6 vs 5.7 months; $\mathrm{P}=0.002)$ and $\mathrm{OS}(38.9$ vs 12.5 months; $\mathrm{P}=0.002$ ). This study confirmed that blinatumomab is effective in eliminating MRD [51]. After a minimum follow-up of 3 years (median $53.1 \mathrm{~m}$ ), OS has reached a plateau and the median survival has not been reached among the patients with a complete MRD response [52]. Blinatumomab became the first FDAapproved treatment for MRD + B-ALL in 2018 [53].

\section{Blinatumomab for $\mathrm{Ph}+\mathrm{ALL}$}

Clinical trials have been initiated to characterize the activity of blinatumomab in $\mathrm{Ph}+\mathrm{R} / \mathrm{R}$ ALL patients. In a preliminary report, 45 patients were enrolled [54]. 36\% (95\% CI, 22\% to 51\%) CR/CRh were achieved. MRD negativity was $88 \%$ among the patients who achieved CR/ CRh. $44 \%$ of the CR/CRh patients went on to receive allo-HSCT. This rate is consistent with the results from previous studies. Treatment emergent AEs (TEAE) were similar to those reported in other studies.

\section{Blinatumomab in combination therapy for ALL Blinatumomab + tyrosine kinase inhibitors}

Tyrosine kinase inhibitors (TKI) are playing a major role in the therapy for Ph+ALL $[24,26,55,56]$. TKIs in combination with blinatumomab are being evaluated for $\mathrm{Ph}+\mathrm{ALL}$ [57]. Blinatumomab + ponatinib was used in 15 patients with relapsed Ph+ALL [58]. In this retrospective analysis, ponatinib was given daily whereas blinatumomab was given a median of 3 cycles. 14 of the 15 patients achieved cytogenetic remission, with molecular CR in 12 patients. Two patients had CNS relapse while in molecular remission. The follow-up was short (median 8.5 months). A prospective trial is underway to evaluate the chemotherapy-free regimen (NCT03263572).

A group from the Memorial Sloan-Kettering Cancer Center reported a retrospective analysis of 11 patients who received blinatumomab plus one of the TKIs (ponatinib, dasatinib or nilotinib) [59]. Seven of the 11 MRD+ patients became MRD negative. The median follow-up was 7.7 months (range 3.2-16.0 months). Grade 1 CRS was seen in three patients and no patient had neurotoxicity. The blinatumomab and ponatinib combination was reported to have higher risk of liver enzyme abnormality.

Overall, the combination of blinatumomab with TKI was well tolerated. The chemotherapy-fee regimen appears to be promising to serve as a bridge therapy prior to allo-HSCT.

\section{Blintumomab + immune checkpoint inhibitors}

Recently, a multi-center phase I dose-escalation study was initiated to evaluate the combination of blinatumomab with nivolumab and ipilimumab for $R / R$ CD19+ ALL patients [60]. The patients were scheduled to receive up to 5 cycles of blinatumomab and 1 year of nivolumab/ipilimumab. The first part of the study was to evaluate the safety of combining blinatumomab with nivolumab. Once the dose is established, ipilimumab dose escalation will be added. A preliminary report enrolled 8 adults at dose level I. Five patients were evaluable. Common AEs included liver enzyme elevation and chemical pancreatitis. DLT was reported to be Infusionrelated reactions to nivolumab. Four out of five evaluable patients achieved CR with -MRD. It appears that the blinatumomab/nivolumab combination in R/R ALL is well tolerated. The next phase of the study to add ipilimumab is ongoing.

\section{Blinatumomab + chemotherapy}

Hyper-CVAD is a commonly used regimen for ALL therapy [61-66]. In an attempt to improve response rate and quality, blinatumomab was added to hyper-CVAD 
regimen in a phase 2 study [67]. After induction therapy with 4 cycles of Hyper-CVAD, blinatumomab was given as consolidation therapy for a total of 4 cycles. Monoclonal antibodies against CD20 were added for those patients with CD20+ALL. In this study, blinatumomab was also added to the maintenance phase on cycles 4 , 8 and 12 [57]. POMP (6-mercaptopurine, vincristine, methotrexate, prednisone) regimen was used for maintenance on cycles $1-3,5-7,9-11$ and $13-15$. A preliminary report of 17 patients revealed an ORR of $100 \%$. MRD negativity was $93 \%$. Among 14 evaluable patients, 9 patients have completed hyper-CVAD plus blinatumomab sequential therapy and entered maintenance phase. With a median follow-up of 14 months (range, 3-20 months) at the time of the report, the rates of OS and CR were $94 \%$ and $93 \%$, respectively. A transient grade 3 CRS event was reported in one patient, and one had grade 3 neurotoxicity. These two patients both recovered after interruption of blinatumomab and prompt steroid therapy. Therefore, the sequential combination of HyperCVAD and blinatumomab was well tolerated as frontline regimen in B-ALL. This study attempts to reduce HyperCVAD chemotherapy to 4 cycles from conventional 8 cycles by adding 4 cycles of blinatumomab. This study also added blinatumomab in the maintenance phase so that the POMP maintenance time is reduced from usually
3 years to 12 months. In conclusion, this study may lead to reduction of chemotherapy toxicity and duration of maintenance therapy.

\section{miniHCVD + inotuzumab + blinatumomab}

Inotuzumab ozogamicin (INO) is CD22 antibody-drug conjugate which has been approved for R/R ALL [61, 6877]. Both INO and blinatumomab (blina) were superior as single agent to salvage chemotherapies in R/R ALL [37, 74]. Blinatumomab is being studied in combination with the miniHCVD-INO regimen for newly diagnosed ALL patients [71, 78-80]. Rituximab was added in patients with CD20 expression $\geq 20 \%$. There were three phases in the therapy regimen: intensification, consolidation and maintenance. In the intensification phase, 4 cycles of miniHCVD was followed by 4 cycles of INO. Two lower doses of INO was given in each cycle. 4 cycles of blinatumomab was given in the consolidation phase. In th maintenance phase, 4 more cycles of blinatumomab were given on month 4, 8, 12 and 16. The POMP regimen was given in the maintenance as described above for a total of 12 cycles. Addition of blinatumomab makes it possible to reduce POMP maintenance cycles from 3 years to 12 months.

Table 1 Ongoing clinical trials of combined treatment with blinatumomab for B-ALL

\begin{tabular}{|c|c|c|c|}
\hline NCT Number & Patients & Treatment & Phase \\
\hline NCT02877303 & Newly diagnosed B-ALL & Blinatumomab + hyper-CVAD & Phase 2 \\
\hline NCT03367299 & Untreated Ph-CD19+B-ALL & Blinatumomab + chemotherapy & Phase 2 \\
\hline NCT03480438 & Older newly diagnosed Ph/BCR-ABL-CD19+B-ALL & Blinatumomab + chemotherapy & Phase 2 \\
\hline NCT03518112 & $\mathrm{Ph}-\mathrm{R} / \mathrm{R}$ B-ALL & Blinatumomab + chemotherapy & Phase 2 \\
\hline NCT03914625 & $\begin{array}{l}\text { Newly diagnosed standard risk or down syndrome } \\
\text { B-ALL and localized B-Lly }\end{array}$ & Blinatumomab + chemotherapy & Phase 3 \\
\hline \multirow[t]{2}{*}{ NCT02143414 } & Older newly diagnosed Ph-B-ALL & Blinatumomab + chemotherapy & Phase 2 \\
\hline & Older newly diagnosed or R/R Ph+ (Ph-like) B-ALL & Blinatumomab + dasatinib + prednisone & \\
\hline NCT03263572 & $\mathrm{Ph} / \mathrm{BCR}-\mathrm{ABL}+\mathrm{B}-\mathrm{ALL}$ & Blinatumomab + ponatinib + cytarabine + Methotrexate & Phase 2 \\
\hline NCT03147612 & $\mathrm{R} / \mathrm{R} \mathrm{Ph}+/ \mathrm{BCR}-\mathrm{ABL}+\mathrm{B}-\mathrm{ALL}$ & Blinatumomab + ponatinib + chemotherapy & Phase 2 \\
\hline NCT02744768 & Newly diagnosed adult Ph+B-ALL & Blinatumomab + dasatinib & Phase 2 \\
\hline NCT03605589 & R/R B-ALL & Blinatumomab + pembrolizumab & Phase 1 \\
\hline NCT03160079 & R/R B-ALL & Blinatumomab + pembrolizumab & Phase $1 / 2$ \\
\hline NCT03512405 & R/R B-ALL & Blinatumomab + pembrolizumab & Phase $1 / 2$ \\
\hline NCT02879695 & R/R B-ALL & Blinatumomab + nivolumab with or without ipilimumab & Phase 1 \\
\hline NCT02997761 & R/R B-ALL & Blinatumomab + ibrutinib & Phase 2 \\
\hline NCT03739814 & Newly diagnosed or R/R CD22+ B-ALL & Blinatumomab + inotuzumab ozogamicin & Phase 2 \\
\hline NCT03751709 & $\mathrm{R} / \mathrm{R} C \mathrm{C} 19+\mathrm{B}-\mathrm{ALL}$ & Blinatumomab + HMCT & Phase 1 \\
\hline NCT03849651 & Hematologic malignancies & Blinatumomab + DLI & Phase 2 \\
\hline NCT03982992 & B-ALL with MC or MRD-positive after allo-HSCT & Blinatumomab + DLI & Phase 2 \\
\hline NCT02790515 & R/R hematologic malignancies & Blinatumomab + haploidentical HCT & Phase 2 \\
\hline
\end{tabular}

$R / R$ relapsed/refractory; $B$ - $A L L$ B-cell acute lymphoblastic leukemia; HMCT HLA-mismatched cellular therapy; BM bone marrow; $B$ - $L l y$ B-Lymphoblastic lymphoma; $H C T$ hematopoietic cell transplant; $D L /$ donor lymphocyte infusion; $M C$ mixed chimerism; MRD minimal residual disease; allo-HSCT allogeneic hematopoietic stem cell transplantation 
In a recent report, 58 newly diagnosed elderly B-ALL patients were enrolled [79]. Fifty-four patients were evaluable for morphological responses and 57 patients were evaluable for MRD status. Both ORR and MRD negativity were $95 \%$. Sinus occlusive syndrome (SOS) was known to be associated with INO. SOS was seen in $8-11 \%$ of the patients. With a median follow-up of 28 months, the 3-year OS rate was estimated to be $54 \%$. Therefore, it appears that adding blinatumomab to the miniHCVD + INO regimen was safe and effective in elderly patients with newly diagnosed ALL.

The miniHCVD + INO +/ - blina regimen is also being studied in R/R ALL [78, 80]. In a recent report, 17 out of 84 patients received miniHCVD + INO + blina [80]. The SOS rate was markedly reduced to $0 \%$ from $15 \%$ after INO was split to two lower doses each cycle. Although the schedules are complicated, this lowintensity miniHCVD + INO + blina regimen appears to be well tolerated and effective in R/R ALL patients. The long interval between INO and allo-HSCT as well as split-dose INO has markedly reduced the SOS risk.

\section{Conclusion and future perspectives}

Blinatumomab has been approved for patients with R/R B-ALL and MRD + B-ALL. Blinatumomab is being studied for use in frontline therapy of newly diagnosed B-ALL. Adding blinatumomab to the low intensity miniHCVD + INO regimen in the consolidation and maintenance phases appears to be promising. The mechanisms of blinatumomab resistance and predictive biomarkers for response remain uncertain [81]. Blinatumomab in maintenance therapy appears to be promising to minimize chemotherapy and reduce therapy duration. More BiTE antibodies are coming to clinical applications $[82,83]$. New regimens incorporating blinatumomab may lead to new therapy modalities for ALL. Combination of blinatumomab with TKIs or with immune checkpoint inhibitors are ongoing and may result in chemotherapy-free regimens for ALL (Table 1).

\begin{abstract}
Abbreviations
CR: complete remission; B-ALL: B cell acute lymphoblastic leukemia; r/r: relapsed and refractory; SOC: standard of care; OS: overall survival; m: months; MRD: minimal residual disease; FDA: Food and Drug Administration; AEs: adverse effects; CRh: CR with partial hematologic recovery; allo-HSCT: allogeneic hematopoietic stem cell transplantation; CL: clearance; cIVi: continuous intravenous infusion; Css: steady-state concentrations; NEs: neurologic events; CRS: cytokine release syndrome; TKIs: tyrosine kinase inhibitors; DLI: donor lymphocyte infusions.
\end{abstract}

\section{Acknowledgements}

DL is a Professor of Medicine at the New York Medical College and Westchester Medical Center, Valhalla, NY 10595, USA.

\section{Authors' contributions}

$\mathrm{DL}$ and JZ designed the study and drafted the manuscript. All authors participated in the revision of the manuscript. All authors read and approved the final manuscript.

\section{Funding}

The study is partly supported by the Affiliated Cancer Hospital of Zhengzhou University, Zhengzhou, China.

\section{Availability of data and materials}

The material supporting the conclusion of this review has been included within the article.

\section{Ethics approval and consent to participate}

This is not applicable for this review.

\section{Consent for publication}

This is not applicable for this review.

\section{Competing interests}

The authors declare that they have no competing interests.

\section{Author details}

1 Department of Hematology, The Affiliated Cancer Hospital of Zhengzhou University and Henan Cancer Hospital, Zhengzhou, China. ${ }^{2}$ Department of Medicine, New York Medical College and Westchester Medical Center, Valhalla, NY 10595, USA.

Received: 7 October 2019 Accepted: 31 October 2019

Published online: 06 November 2019

\section{References}

1. Hoelzer D, Bassan R, Dombret H, Fielding A, Ribera JM, Buske C, Committee EG. Acute lymphoblastic leukaemia in adult patients: ESMO Clinical Practice Guidelines for diagnosis, treatment and follow-up. Ann Oncol. 2016;27(suppl 5):v69-82.

2. Gokbuget N, Stanze D, Beck J, Diedrich H, Horst HA, Huttmann A, Kobbe G, Kreuzer KA, Leimer L, Reichle A, Schaich M, Schwartz S, Serve H, Starck M, Stelljes M, Stuhlmann R, Viardot A, Wendelin K, Freund M, Hoelzer D, German Multicenter Study Group for Adult Acute Lymphoblastic L. Outcome of relapsed adult lymphoblastic leukemia depends on response to salvage chemotherapy, prognostic factors, and performance of stem cell transplantation. Blood. 2012;120(10):2032-41.

3. Frey NV, Luger SM. How I treat adults with relapsed or refractory Philadelphia chromosome-negative acute lymphoblastic leukemia. Blood. 2015;126(5):589-96.

4. Kantarjian HM, Thomas D, Ravandi F, Faderl S, Jabbour E, Garcia-Manero G, Pierce S, Shan J, Cortes J, O'Brien S. Defining the course and prognosis of adults with acute lymphocytic leukemia in first salvage after induction failure or short first remission duration. Cancer. 2010;116(24):5568-74.

5. Oriol A, Vives S, Hernandez-Rivas JM, Tormo M, Heras I, Rivas C, Bethencourt C, Moscardo F, Bueno J, Grande C, del Potro E, Guardia R, Brunet S, Bergua J, Bernal T, Moreno MJ, Calvo C, Bastida P, Feliu E, Ribera JM, Programa Espanol de Tratamiento en Hematologia G. Outcome after relapse of acute lymphoblastic leukemia in adult patients included in four consecutive risk-adapted trials by the PETHEMA study group. Haematologica. 2010;95(4):589-96.

6. Gokbuget N, Dombret H, Ribera JM, Fielding AK, Advani A, Bassan R, Chia V, Doubek M, Giebel S, Hoelzer D, Ifrah N, Katz A, Kelsh M, Martinelli G, Morgades M, O'Brien S, Rowe JM, Stieglmaier J, Wadleigh M, Kantarjian H. International reference analysis of outcomes in adults with B-precursor Ph-negative relapsed/refractory acute lymphoblastic leukemia. Haematologica. 2016;101(12):1524-33.

7. van Dongen JJ, van der Velden VH, Bruggemann M, Orfao A. Minimal residual disease diagnostics in acute lymphoblastic leukemia: need for sensitive, fast, and standardized technologies. Blood. 2015;125(26):3996-4009. 
8. Cheng S, Inghirami G, Cheng S, Tam W. Simple deep sequencing-based post-remission MRD surveillance predicts clinical relapse in B-ALL. J Hematol Oncol. 2018;11(1):105.

9. Jastaniah W, Elimam N, Abdalla K, AIAzmi AA, Elgaml AM, Alkassar A, Daghistani M, Felimban S. Early vs late MRD response- and risk-based treatment intensification of childhood acute lymphoblastic leukemia: a prospective pilot study from Saudi Arabia. Exp Hematol Oncol. 2018;7(1):29.

10. van Dongen JJ, Seriu T, Panzer-Grumayer ER, Biondi A, Pongers-Willemse MJ, Corral L, Stolz F, Schrappe M, Masera G, Kamps WA, Gadner H, van Wering ER, Ludwig WD, Basso G, de Bruijn MA, Cazzaniga G, Hettinger K, van den Berg A, Hop WC, Riehm H, Bartram CR. Prognostic value of minimal residual disease in acute lymphoblastic leukaemia in childhood. Lancet. 1998;352(9142):1731-8.

11. Eckert C, Biondi A, Seeger K, Cazzaniga G, Hartmann R, Beyermann B, Pogodda M, Proba J, Henze G. Prognostic value of minimal residual disease in relapsed childhood acute lymphoblastic leukaemia. Lancet. 2001;358(9289):1239-41.

12. Gokbuget N, Kneba M, Raff T, Trautmann H, Bartram CR, Arnold R, Fietkau R, Freund M, Ganser A, Ludwig WD, Maschmeyer G, Rieder H, Schwartz S, Serve H, Thiel E, Bruggemann M, Hoelzer D, German Multicenter Study Group for Adult Acute Lymphoblastic L. Adult patients with acute lymphoblastic leukemia and molecular failure display a poor prognosis and are candidates for stem cell transplantation and targeted therapies. Blood. 2012;120(9):1868-76.

13. Bassan R, Spinelli O, Oldani E, Intermesoli T, Tosi M, Peruta B, Rossi G, Borlenghi E, Pogliani EM, Terruzzi E, Fabris P, Cassibba V, Lambertenghi-Deliiiers G, Cortelezzi A, Bosi A, Gianfaldoni G, Ciceri F, Bernardi M, Gallamini A, Mattei D, Di Bona E, Romani C, Scattolin AM, Barbui T, Rambaldi A. Improved risk classification for risk-specific therapy based on the molecular study of minimal residual disease (MRD) in adult acute lymphoblastic leukemia (ALL). Blood. 2009;113(18):4153-62.

14. Holowiecki J, Krawczyk-Kulis M, Giebel S, Jagoda K, Stella-Holowiecka B, Piatkowska-Jakubas B, Paluszewska M, Seferynska I, Lewandowski K, Kielbinski M, Czyz A, Balana-Nowak A, Krol M, Skotnicki AB, Jedrzejczak WW, Warzocha K, Lange A, Hellmann A. Status of minimal residual disease after induction predicts outcome in both standard and high-risk Ph-negative adult acute lymphoblastic leukaemia. The Polish Adult Leukemia Group ALL 4-2002 MRD Study. Br J Haematol. 2008;142(2):227-37.

15. Borowitz MJ, Devidas M, Hunger SP, Bowman WP, Carroll AJ, Carroll WL, Linda S, Martin PL, Pullen DJ, Viswanatha D, Willman CL, Winick N, Camitta BM, Children's Oncology G. Clinical significance of minimal residual disease in childhood acute lymphoblastic leukemia and its relationship to other prognostic factors: a Children's Oncology Group study. Blood. 2008;111(12):5477-85.

16. Beldjord K, Chevret S, Asnafi V, Huguet F, Boulland ML, Leguay T, Thomas X, Cayuela JM, Grardel N, Chalandon Y, Boissel N, Schaefer B, Delabesse E, Cave H, Chevallier P, Buzyn A, Fest T, Reman O, Vernant JP, Lheritier V, Bene MC, Lafage M, Macintyre E, Ifrah N, Dombret H, Group for Research on Adult Acute Lymphoblastic L. Oncogenetics and minimal residual disease are independent outcome predictors in adult patients with acute lymphoblastic leukemia. Blood. 2014;123(24):3739-49.

17. Ravandi F, Jorgensen JL, O'Brien SM, Jabbour E, Thomas DA, Borthakur G, Garris R, Huang X, Garcia-Manero G, Burger JA, Ferrajoli A, Wierda W, Kadia T, Jain N, Wang SA, Konoplev S, Kebriaei P, Champlin RE, McCue D, Estrov Z, Cortes JE, Kantarjian HM. Minimal residual disease assessed by multi-parameter flow cytometry is highly prognostic in adult patients with acute lymphoblastic leukaemia. Br J Haematol. 2016;172(3):392-400.

18. Berry DA, Zhou S, Higley H, Mukundan L, Fu S, Reaman GH, Wood BL, Kelloff GJ, Jessup JM, Radich JP. Association of minimal residual disease with clinical outcome in pediatric and adult acute lymphoblastic leukemia: a meta-analysis. JAMA Oncol. 2017;3(7):e170580.

19. Ribrag V, Koscielny S, Bosq J, Leguay T, Casasnovas O, Fornecker L-M, Recher C, Ghesquieres H, Morschhauser F, Girault S, Gouill SL, Ojeda-Uribe M, Mariette C, Cornillon J, Cartron G, Verge V, Chassagne-Clément C, Dombret H, Coiffier B, Lamy T, Tilly H, Salles G. Rituximab and dose-dense chemotherapy for adults with Burkitt's lymphoma: a randomised, controlled, open-label, phase 3 trial. Lancet. 2016;387(10036):2402-11.

20. Thomas DA, Faderl S, Cortes J, O'Brien S, Giles FJ, Kornblau SM, GarciaManero G, Keating MJ, Andreeff M, Jeha S, Beran M, Verstovsek S, Pierce S, Letvak L, Salvado A, Champlin R, Talpaz M, Kantarjian H. Treatment of
Philadelphia chromosome-positive acute lymphocytic leukemia with hyper-CVAD and imatinib mesylate. Blood. 2004;103(12):4396-407.

21. Thomas DA, Faderl S, O'Brien S, Bueso-Ramos C, Cortes J, Garcia-Manero G, Giles FJ, Verstovsek S, Wierda WG, Pierce SA, Shan J, Brandt M, Hagemeister FB, Keating MJ, Cabanillas F, Kantarjian H. Chemoimmunotherapy with hyper-CVAD plus rituximab for the treatment of adult Burkitt and Burkitt-type lymphoma or acute lymphoblastic leukemia. Cancer. 2006;106(7):1569-80

22. Thomas DA, O'Brien S, Cortes J, Giles FJ, Faderl S, Verstovsek S, Ferrajoli A, Koller C, Beran M, Pierce S, Ha CS, Cabanillas F, Keating MJ, Kantarjian H. Outcome with the hyper-CVAD regimens in lymphoblastic lymphoma. Blood. 2004;104(6):1624-30.

23. Thomas DA, O'Brien S, Faderl S, Garcia-Manero G, Ferrajoli A, Wierda W, Ravandi F, Verstovsek S, Jorgensen JL, Bueso-Ramos C, Andreeff M, Pierce S, Garris R, Keating MJ, Cortes J, Kantarjian HM. Chemoimmunotherapy with a modified hyper-CVAD and rituximab regimen improves outcome in de novo Philadelphia chromosome-negative precursor B-lineage acute lymphoblastic leukemia. J Clin Oncol. 2010;28(24):3880-9.

24. Cortes JE, Apperley JF, DeAngelo DJ, Deininger MW, Kota VK, Rousselot P, Gambacorti-Passerini C. Management of adverse events associated with bosutinib treatment of chronic-phase chronic myeloid leukemia: expert panel review. J Hematol Oncol. 2018;11(1):143.

25. Curran E, Stock W. How I treat acute lymphoblastic leukemia in older adolescents and young adults. Blood. 2015;125(24):3702-10.

26. Rossari F, Minutolo F, Orciuolo E. Past, present, and future of Bcr-Abl inhibitors: from chemical development to clinical efficacy. J Hematol Oncol. 2018;11(1):84.

27. Carter RH, Myers R. Germinal center structure and function: lessons from CD19. Semin Immunol. 2008;20(1):43-8.

28. Carter RH, Wang Y, Brooks S. Role of CD19 signal transduction in B cell biology. Immunol Res. 2002;26(1-3):45-54.

29. Del Nagro CJ, Otero DC, Anzelon AN, Omori SA, Kolla RV, Rickert RC. CD19 function in central and peripheral B-cell development. Immunol Res. 2005;31(2):119-31.

30. Wang K, Wei G, Liu D. CD19: a biomarker for B cell development, lymphoma diagnosis and therapy. Exp Hematol Oncol. 2012;1(1):36.

31. Wang J, Hu Y, Huang H. Current development of chimeric antigen receptor T-cell therapy. Stem Cell Investig. 2018:5:44.

32. Wei G, Ding L, Wang J, Hu Y, Huang H. Advances of CD19-directed chimeric antigen receptor-modified T cells in refractory/relapsed acute lymphoblastic leukemia. Exp Hematol Oncol. 2017;6(1):10.

33. Zhang C, Liu J, Zhong JF, Zhang X. Engineering CAR-T cells. Biomark Res. 2017;5(1):22.

34. Nagorsen D, Baeuerle PA. Immunomodulatory therapy of cancer with T cell-engaging BiTE antibody blinatumomab. Exp Cell Res. 2011:317(9):1255-60

35. Loffler A, Kufer P, Lutterbuse R, Zettl F, Daniel PT, Schwenkenbecher JM, Riethmuller G, Dorken B, Bargou RC. A recombinant bispecific singlechain antibody, CD19 $\times$ CD3, induces rapid and high lymphoma-directed cytotoxicity by unstimulated T lymphocytes. Blood. 2000;95(6):2098-103.

36. Wu J, Fu J, Zhang M, Liu D. Blinatumomab: a bispecific T cell engager (BiTE) antibody against CD19/CD3 for refractory acute lymphoid leukemia. J Hematol Oncol. 2015:8(1):104.

37. Kantarjian H, Stein A, Gökbuget N, Fielding AK, Schuh AC, Ribera J-M, Wei A, Dombret H, Foà R, Bassan R, Arslan Ö, Sanz MA, Bergeron J, Demirkan F, Lech-Maranda E, Rambaldi A, Thomas X, Horst H-A, Brüggemann M, Klapper W, Wood BL, Fleishman A, Nagorsen D, Holland C, Zimmerman Z, Topp MS. Blinatumomab versus chemotherapy for advanced acute lymphoblastic leukemia. N Engl J Med. 2017;376(9):836-47.

38. Topp MS, Gökbuget N, Stein AS, Zugmaier G, O'Brien S, Bargou RC, Dombret H, Fielding AK, Heffner L, Larson RA, Neumann S, Foà R, Litzow M, Ribera J-M, Rambaldi A, Schiller G, Brüggemann M, Horst HA, Holland C, Jia C, Maniar T, Huber B, Nagorsen D, Forman SJ, Kantarjian HM. Safety and activity of blinatumomab for adult patients with relapsed or refractory B-precursor acute lymphoblastic leukaemia: a multicentre, singlearm, phase 2 study. Lancet Oncol. 2015;16(1):57-66.

39. Nägele V, Kratzer A, Zugmaier G, Holland C, Hijazi Y, Topp MS, Gökbuget $\mathrm{N}$, Baeuerle PA, Kufer P, Wolf A, Klinger M. Changes in clinical laboratory parameters and pharmacodynamic markers in response to blinatumomab treatment of patients with relapsed/refractory ALL. Exp Hematol Oncol. 2017;6(1):14 
40. Porter D, Frey N, Wood PA, Weng Y, Grupp SA. Grading of cytokine release syndrome associated with the CART cell therapy tisagenlecleucel. J Hematol Oncol. 2018;11(1):35.

41. Neelapu SS, Tummala S, Kebriaei P, Wierda W, Locke FL, Lin Y, Jain N, Daver N, Gulbis AM, Adkins S, Rezvani K, Hwu P, Shpall EJ. Toxicity management after chimeric antigen receptor T cell therapy: one size does not fit 'ALL' Nat Rev Clin Oncol. 2018;15(4):218

42. Vakharia P, Nardone B, Budris W, Hoshizaki K, Frankfurt O, West DP. Blinatumomab and pancreatitis: an analysis of FAERS, EudraVigilance, and a large urban U.S. patient population data. Leuk Lymphoma. 2018;59(7):1759-61.

43. Przepiorka D, Ko CW, Deisseroth A, Yancey CL, Candau-Chacon R, Chiu HJ, Gehrke BJ, Gomez-Broughton C, Kane RC, Kirshner S, Mehrotra N, Ricks TK, Schmiel D, Song P, Zhao P, Zhou Q, Farrell AT, Pazdur R. FDA approval: blinatumomab. Clin Cancer Res. 2015;21(18):4035-9.

44. Stein A, Franklin JL, Chia VM, Arrindell D, Kormany W, Wright J, Parson M, Amouzadeh HR, Choudhry J, Joseph G. Benefit-risk assessment of blinatumomab in the treatment of relapsed/refractory B-cell precursor acute lymphoblastic leukemia. Drug Saf. 2018;42(5):587-601.

45. Topp MS, Gokbuget N, Zugmaier G, Klappers P, Stelljes M, Neumann S, Viardot A, Marks R, Diedrich H, Faul C, Reichle A, Horst HA, Bruggemann M, Wessiepe D, Holland C, Alekar S, Mergen N, Einsele H, Hoelzer D, Bargou RC. Phase II trial of the anti-CD19 bispecific T cell-engager blinatumomab shows hematologic and molecular remissions in patients with relapsed or refractory B-precursor acute lymphoblastic leukemia. J Clin Oncol. 2014;32(36):4134-40.

46. Topp MS, Gokbuget N, Zugmaier G, Degenhard E, Goebeler ME, Klinger M, Neumann SA, Horst HA, RaffT, Viardot A, Stelljes M, Schaich M, Kohne-Volland R, Bruggemann M, Ottmann OG, Burmeister T, Baeuerle PA, Nagorsen D, Schmidt M, Einsele H, Riethmuller G, Kneba M, Hoelzer D, Kufer P, Bargou RC. Long-term follow-up of hematologic relapse-free survival in a phase 2 study of blinatumomab in patients with MRD in B-lineage ALL. Blood. 2012;120(26):5185-7.

47. Barlev A, Lin VW, Katz A, Hu K, Cong Z, Barber B. Estimating long-term survival of adults with philadelphia chromosome-negative relapsed/ refractory B-precursor acute lymphoblastic leukemia treated with blinatumomab using historical data. Adv Ther. 2017;34(1):148-55.

48. Kantarjian $H$, Stein A, Gokbuget N, Fielding AK, Schuh AC, Ribera JM, Wei A, Dombret H, Foa R, Bassan R, Arslan O, Sanz MA, Bergeron J, Demirkan F, Lech-Maranda E, Rambaldi A, Thomas X, Horst HA, Bruggemann M, Klapper W, Wood BL, Fleishman A, Nagorsen D, Holland C, Zimmerman Z, Topp MS. Blinatumomab versus chemotherapy for advanced acute lymphoblastic leukemia. N Engl J Med. 2017;376(9):836-47.

49. Topp MS, Kufer P, Gokbuget N, Goebeler M, Klinger M, Neumann S, Horst HA, Raff T, Viardot A, Schmid M, Stelljes M, Schaich M, Degenhard E, Kohne-Volland R, Bruggemann M, Ottmann O, Pfeifer H, Burmeister T, Nagorsen D, Schmidt M, Lutterbuese R, Reinhardt C, Baeuerle PA, Kneba M, Einsele H, Riethmuller G, Hoelzer D, Zugmaier G, Bargou RC. Targeted therapy with the T-cell-engaging antibody blinatumomab of chemotherapy-refractory minimal residual disease in B-lineage acute lymphoblastic leukemia patients results in high response rate and prolonged leukemiafree survival. J Clin Oncol. 2011;29(18):2493-8.

50. Gokbuget N, Zugmaier G, Klinger M, Kufer P, Stelljes M, Viardot A, Horst HA, Neumann S, Bruggemann M, Ottmann OG, Burmeister T, Wessiepe D, Topp MS, Bargou R. Long-term relapse-free survival in a phase 2 study of blinatumomab for the treatment of patients with minimal residual disease in B-lineage acute lymphoblastic leukemia. Haematologica. 2017;102(4):e132-5.

51. Gokbuget N, Dombret H, Bonifacio M, Reichle A, Graux C, Faul C, Diedrich H, Topp MS, Bruggemann M, Horst HA, Havelange V, Stieglmaier J, Wessels H, Haddad V, Benjamin JE, Zugmaier G, Nagorsen D, Bargou RC. Blinatumomab for minimal residual disease in adults with B-cell precursor acute lymphoblastic leukemia. Blood. 2018;131(14):1522-31.

52. Goekbuget N, Dombret H, Zugmaier G, Bonifacio M, Graux C, Faul C, Topp MS, Brüggemann M, Taylor K, Bargou R. Blinatumomab for minimal residual disease ( $\mathrm{mrd}$ ) in adults with B-cell precursor acute lymphoblastic leukemia (BCP-ALL): median overall survival (OS) is not reached in complete mrd responders at a median follow-up of 53.1 months. Blood. 2018;132(1):554.

53. Jen EY, Xu Q, Schetter A, Przepiorka D, Shen YL, Roscoe D, Sridhara R, Deisseroth A, Philip R, Farrell AT, Pazdur R. FDA Approval: blinatumomab for patients with B-cell precursor acute lymphoblastic leukemia in morphologic remission with minimal residual disease. Clin Cancer Res. 2019;25(2):473-7.

54. Martinelli G, Boissel N, Chevallier P, Ottmann O, Gokbuget N, Topp MS, Fielding AK, Rambaldi A, Ritchie EK, Papayannidis C, Sterling LR, Benjamin J, Stein A. Complete hematologic and molecular response in adult patients with relapsed/refractory philadelphia chromosome-positive B-precursor acute lymphoblastic leukemia following treatment with blinatumomab: results from a phase II, single-arm. Multicenter Study. J Clin Oncol. 2017:35(16):1795-802.

55. Ling $Y$, Xie $Q$, Zhang Z, Zhang H. Protein kinase inhibitors for acute leukemia. Biomark Res. 2018;6(1):8.

56. Jabbour E, Kantarjian H, Ravandi F, Thomas D, Huang X, Faderl S, Pemmaraju N, Daver N, Garcia-Manero G, Sasaki K, Cortes J, Garris R, Yin CC, Khoury JD, Jorgensen J, Estrov Z, Bohannan Z, Konopleva M, Kadia T, Jain N, DiNardo C, Wierda W, Jeanis V, O'Brien S. Combination of hyperCVAD with ponatinib as first-line therapy for patients with Philadelphia chromosome-positive acute lymphoblastic leukaemia: a single-centre, phase 2 study. Lancet Oncol. 2015;16(15):1547-55.

57. Liu D, Zhao J, Song Y, Luo X, Yang T. Clinical trial update on bispecific antibodies, antibody-drug conjugates, and antibody-containing regimens for acute lymphoblastic leukemia. J Hematol Oncol. 2019;12(1):15.

58. Couturier M-A, Thomas X, Huguet F, Berthon C, Simand C, Hicheri Y, Hunault M, Chevallier P. Blinatumomab + ponatinib for relapsed Ph1positive acute lymphoblastic leukemia: the French experience. Blood. 2018;132(Suppl 1):4014.

59. King AC, Pappacena J, Tallman MS, Park JH, Geyer MB. Blinatumomab administered concurrently with oral tyrosine kinase inhibitor therapy is a well-tolerated consolidation strategy and eradicates measurable residual disease in adults with Philadelphia chromosome positive acute lymphoblastic leukemia. Blood. 2018;132(Suppl 1):1414.

60. Webster J, Luskin MR, Prince GT, DeZern AE, DeAngelo DJ, Levis MJ, Blackford A, Sharon E, Streicher H, Luznik L, Gojo I. Blinatumomab in combination with immune checkpoint inhibitors of PD-1 and CTLA-4 in adult patients with relapsed/refractory (R/R) CD19 positive B-Cell acute lymphoblastic leukemia (ALL): preliminary results of a phase I study. Blood. 2018;132(Suppl 1):557.

61. Kantarjian H, Thomas D, O'Brien S, Cortes J, Giles F, Jeha S, BuesoRamos CE, Pierce S, Shan J, Koller C, Beran M, Keating M, Freireich EJ. Long-term follow-up results of hyperfractionated cyclophosphamide, vincristine, doxorubicin, and dexamethasone (Hyper-CVAD), a dose-intensive regimen, in adult acute lymphocytic leukemia. Cancer. 2004;101(12):2788-801.

62. Kantarjian HM, O'Brien S, Smith TL, Cortes J, Giles FJ, Beran M, Pierce S, Huh Y, Andreeff M, Koller C, Ha CS, Keating MJ, Murphy S, Freireich EJ. Results of treatment with hyper-CVAD, a dose-intensive regimen, in adult acute lymphocytic leukemia. J Clin Oncol. 2000;18(3):547-61.

63. Ravandi F, O'Brien S, Thomas D, Faderl S, Jones D, Garris R, Dara S, Jorgensen J, Kebriaei P, Champlin R, Borthakur G, Burger J, Ferrajoli A, GarciaManero G, Wierda W, Cortes J, Kantarjian H. First report of phase 2 study of dasatinib with hyper-CVAD for the frontline treatment of patients with Philadelphia chromosome-positive $(\mathrm{Ph}+)$ acute lymphoblastic leukemia. Blood. 2010;116(12):2070-7.

64. Wang M, Fayad L, Cabanillas F, Hagemeister F, McLaughlin P, Rodriguez MA, Kwak LW, Zhou Y, Kantarjian H, Romaguera J. Phase 2 trial of rituximab plus hyper-CVAD alternating with rituximab plus methotrexatecytarabine for relapsed or refractory aggressive mantle cell lymphoma. Cancer. 2008;113(10):2734-41.

65. Faderl S, Thomas DA, O'Brien S, Ravandi F, Garcia-Manero G, Borthakur G, Ferrajoli A, Verstovsek S, Ayoubi M, Rytting M, Feliu J, Kantarjian HM. Augmented hyper-CVAD based on dose-intensified vincristine, dexamethasone, and asparaginase in adult acute lymphoblastic leukemia salvage therapy. Clin Lymphoma Myeloma Leuk. 2011;11(1):54-9.

66. Garcia-Manero G, Kantarjian HM. The hyper-CVAD regimen in adult acute lymphocytic leukemia. Hematol Oncol Clin North Am. 2000;14(6):1381-96.

67. Richard-Carpentier G, Kantarjian HM, Short NJ, Ravandi F, Ferrajoli A Schroeder HM, Khouri M, Garcia-Manero G, Montalban Bravo G, Cortes JE, Jain N, Konopleva MY, Takahashi K, Sasaki K, Garris RE, Jabbour EJ. A phase ii study of the hyper-CVAD regimen in sequential combination with blinatumomab as frontline therapy for adults with B-cell acute lymphoblastic leukemia (B-ALL). Blood. 2018;132(Suppl 1):32. 
68. DiJoseph JF, Armellino DC, Boghaert ER, Khandke K, Dougher MM, Sridharan L, Kunz A, Hamann PR, Gorovits B, Udata C, Moran JK, Popplewell AG, Stephens S, Frost P, Damle NK. Antibody-targeted chemotherapy with CMC-544: a CD22-targeted immunoconjugate of calicheamicin for the treatment of B-lymphoid malignancies. Blood. 2004;103(5):1807-14.

69. DiJoseph JF, Dougher MM, Armellino DC, Evans DY, Damle NK. Therapeutic potential of CD22-specific antibody-targeted chemotherapy using inotuzumab ozogamicin (CMC-544) for the treatment of acute lymphoblastic leukemia. Leukemia. 2007;21:2240.

70. Ereño-Orbea J, Sicard T, Cui H, Mazhab-Jafari MT, Benlekbir S, Guarné A, Rubinstein $\mathrm{J}$, Julien J-P. Molecular basis of human CD22 function and therapeutic targeting. Nat Commun. 2017;8(1):764.

71. Kantarjian $\mathrm{H}$, Jabbour E. Incorporating immunotherapy into the treatment strategies of b-cell adult acute lymphoblastic leukemia: the role of blinatumomab and inotuzumab ozogamicin. Am Soc Clin Oncol Educ Book. 2018;38:574-8.

72. Kantarjian H, Thomas D, Jorgensen J, Jabbour E, Kebriaei P, Rytting M, York S, Ravandi F, Kwari M, Faderl S, Rios MB, Cortes J, Fayad L, Tarnai R, Wang SA, Champlin R, Advani A, O'Brien S. Inotuzumab ozogamicin, an anti-CD22-calecheamicin conjugate, for refractory and relapsed acute lymphocytic leukaemia: a phase 2 study. Lancet Oncol. 2012;13(4):403-11.

73. Kantarjian $\mathrm{H}$, Thomas D, Jorgensen J, Kebriaei P, Jabbour E, Rytting M, York S, Ravandi F, Garris R, Kwari M, Faderl S, Cortes J, Champlin R, O'Brien S. Results of inotuzumab ozogamicin, a CD22 monoclonal antibody, in refractory and relapsed acute lymphocytic leukemia. Cancer. 2013;119(15):2728-36.

74. Kantarjian HM, DeAngelo DJ, Stelljes M, Martinelli G, Liedtke M, Stock W, Gokbuget N, O'Brien S, Wang K, Wang T, Paccagnella ML, Sleight B, Vandendries E, Advani AS. Inotuzumab ozogamicin versus standard therapy for acute lymphoblastic leukemia. N Engl J Med. 2016;375(8):740-53.

75. Kantarjian HM, Su Y, Jabbour EJ, Bhattacharyya H, Yan E, Cappelleri JC, Marks DI. Patient-reported outcomes from a phase 3 randomized controlled trial of inotuzumab ozogamicin versus standard therapy for relapsed/refractory acute lymphoblastic leukemia. Cancer. 2018;124(10):2151-60.

76. Aujla A, Aujla R, Liu D. Inotuzumab ozogamicin in clinical development for acute lymphoblastic leukemia and non-Hodgkin lymphoma. Biomark Res. 2019;7(1):9.
77. Yu B, Liu D. Antibody-drug conjugates in clinical trials for lymphoid malignancies and multiple myeloma. J Hematol Oncol. 2019;12(1):94.

78. Jabbour E, Sasaki K, Ravandi F, Huang X, Short NJ, Khouri M, Kebriaei P, Burger J, Khoury J, Jorgensen J, Jain N, Konopleva M, Garcia-Manero G, Kadia T, Cortes J, Jacob J, Montalbano K, Garris R, O'Brien S, Kantarjian HM. Chemoimmunotherapy with inotuzumab ozogamicin combined with mini-hyper-CVD, with or without blinatumomab, is highly effective in patients with Philadelphia chromosome-negative acute lymphoblastic leukemia in first salvage. Cancer. 2018;124(20):4044-55.

79. Short NJ, Jabbour EJ, Ravandi F, Huang X, Jain N, Sasaki K, Pemmaraju N, Daver NG, Khoury JD, Jorgensen JL, Alvarado Y, Konopleva MY, GarciaManero G, Kadia TM, Yilmaz M, Borthakur G, Burger JA, Kornblau SM, Wierda WG, DiNardo CD, Ferrajoli A, Nasnas P, Jacob J, Garris RE, Brien SM, Kantarjian HM. Chemoimmunotherapy with inotuzumab ozogamicin combined with mini-hyper-cvd, with or without blinatumomab, for newly diagnosed older patients with philadelphia chromosome-negative acute lymphoblastic leukemia: results from a phase II study. Blood. 2018;132(Suppl 1):36.

80. Sasaki K, Kantarjian HM, Ravandi F, Short NJ, Kebriaei P, Huang X, Rytting ME, Jain N, Konopleva MY, Garcia-Manero G, Champlin RE, Kadia TM, Cortes JE, Estrov ZE, Takahashi K, Mace M, Khouri M, Nasnas P, Jacob J, Garris $\mathrm{RE}$, Jabbour EJ. Sequential combination of low-intensity chemotherapy (mini-hyper-CVD) plus inotuzumab ozogamicin with or without blinatumomab in patients with relapsed/refractory philadelphia chromosomenegative acute lymphoblastic leukemia (ALL): a phase 2 trial. Blood. 2018;132(Suppl 1):553.

81. Wang Z, Han W. Biomarkers of cytokine release syndrome and neurotoxicity related to CAR-T cell therapy. Biomark Res. 2018;6(1):4.

82. Yu S, Liu Q, Han X, Qin S, Zhao W, Li A, Wu K. Development and clinical application of anti-HER2 monoclonal and bispecific antibodies for cancer treatment. Exp Hematol Oncol. 2017;6(1):31.

83. Zhang $X$, Yang Y, Fan D, Xiong D. The development of bispecific antibodies and their applications in tumor immune escape. Exp Hematol Oncol. 2017;6(1):12.

\section{Publisher's Note}

Springer Nature remains neutral with regard to jurisdictional claims in published maps and institutional affiliations.
Ready to submit your research? Choose BMC and benefit from:

- fast, convenient online submission

- thorough peer review by experienced researchers in your field

- rapid publication on acceptance

- support for research data, including large and complex data types

- gold Open Access which fosters wider collaboration and increased citations

- maximum visibility for your research: over 100M website views per year

At BMC, research is always in progress.

Learn more biomedcentral.com/submissions 